\title{
A World in the Balance: The Economy Towards Recession
}

\author{
Giovanni Antonio COSSIGA \\ Correspondence: Presidente Collegio sindaci Policlinico Umberto 1, Università Sapienza, Roma. \\ E-mail: g.cossiga@alice.it
}

Received: June 26, 2019 Accepted: July 28, 2019 Online Published: August 7, 2019

doi:10.5539/res.v11n3p50

URL: https://doi.org/10.5539/res.v11n3p50

\begin{abstract}
The global economy is moving uncertainly towards recession. An economy in the balance that remains uncertain on the threshold of recession, relying on the benevolent contribution of support policies. Without the help of fiscal policy and the complacency of the Central Banks through new liquidity injections, and therefore through easy credit, it can certainly be admitted that the recession would tend to prevail. But the recession is not a bad thing in itself, it's rather the treatment for the evil afflicting the economy: the growing instability of economic systems under the increasing weight of excessive liquidity and an abnormal increase of public and private debt. The result of this negative equation is the growth of the economy sustained by abundant liquidity and credit availability and then a weak and doped development. A development line that cannot go on without the resources of politics. The problem is therefore whether this dependency condition can last. That is, if the economy can find the virtuous energies to reabsorb the accumulated excesses through a sustainable growth. The compulsive use of fiscal policy to fight the damage caused by the serious 2008-2010 crisis has undoubtedly reduced the economic and above all social damage due to the loss of jobs, and therefore helped the recovery. However, the massive use of public debt could hide a dark side. First of all, it fueled a legacy of recessive prices and weak development. And this, despite the large river of liquidity injected into the system by the Central Banks. However, the availability of new liquidity did not defeat the tendency of the economy to deflation and then couldn't support development, which appears generally weak. The US case, which sees the relaunch of development by the fiscal reform that reduces taxation particularly in favor of higher incomes, doesn't seem to be an exception. However, we are facing economies that require the continuous support of political policies in order to confirm their (weak) growth. On the other hand, it's quite clear the dark side created by the trap "liquidity - weak growth" now affecting the global development, although without this trick the world in the balance could fall into recession.
\end{abstract}

Keyword: recession, deflation, world in balance, central banks, weak growth

\section{Introduction}

The global economy seems to be in the balance towards the recession, though not yet in recession. Especially since many of the most authoritative sources is saying that the recession of the economy is not in sight for the near future. In practice, the global economy is moving in a non-synchronous cycle, with the United States closing 2018 with a good 2.6\% and with the prospects for the next two years with a gradual slowdown, up to $1.7 \%$. The April issue of IMF Outlook is envisaging a decline of the economic impact exerted by the fiscal policy reform implemented by the US presidency. As saying that the intervention possibilities of the fiscal policy have been exhausted, as they reached now the threshold of excessive debt. It follows that the possibility to fight the otherwise unstoppable recession march, now seems to be in the hands of monetary policy.

Watching around the world, the situation does not appear very different from that of the USA, although the march of the economy towards recession is more advanced in Europe, South America, South Africa and Australia, while it doesn't now seem yet to shake the foundations of the two Asian giants, China and India. More generally, according to the IMF, the global growth could be maintained at an annual rate of $3.2 \%$ during the coming years. Therefore, basically the world remains in the balance with an inclination towards recession, but in the meantime, we are looking with an unnatural optimism at the actions of the Central Banks that could succeed in saving the economy from the fall in the global recession vortex.

However, Europe seems to be the closest recipient of a declining cycle. And we look above all at the uncertainties coming from the so-called Brexit and from the populist Italy, to motivate the fall in the economy stagnation. Moreover, unfavorable news are also coming from Germany, which seems to be affected by the USA-China trade war and by the new duties imposed by the USA. A fall towards the recession seems to be near then, according to a sort of "bowling logic". So that a fully evident recession in this side of the Atlantic and then in Latin America would have the effect of dragging down 
the US economy and afterwards also the Asian giants.

A perspective that is rejected by the market and by institutions as well, through direct or indirect messages aimed to hit the possible causes of the conjunctural decline noticed in the Europe of the Euro area. Regarding Italy, in recession during the final months of 2018, through a substantial distance taken by the chancelleries of the Euro countries from the Peninsula, guilty of promoting Keynesian policies for electoral purposes, outdated in a country with the public debt/GDP ratio over $132 \%$. Likewise, the concern for the uncertain British policy on the fate of leaving the European Union advises the Union countries to grant a wide delay to the English politics' decision, just to avoid the impact of a hard Brexit, that is an exit without any agreement.

Basically, there is a widespread concern about this balance towards recession. At the same time, however, it's persisting the usual trust in the prerogatives of the main Central Banks in counteracting the descent of the global economy into the recessionary sub-world. A concern that should be shared, indeed. We cannot imagine, on the other hand, that an eventual downturn into half the world, including Europe and the USA, may not involve also the emerging countries and in particular China. The possibility for a fast growth like during the 2008-2010 financial crisis may not be available yet. Indeed, everything leads us to suppose that the long run of the Chinese economy could see a sharp stop, in the hypothesis of a reversal in the global economy.

\section{Method}

\subsection{The Recession Is Like a Vertigo or Rather an Adaptation of the Economy to the Rhythms of Nature}

The conjuncture cycle is a dystonia of the natural order, but it is also a peculiar tool of the social order. It's anyway a great trouble, because the stable economy follows a linear trend that is coordinated with the evolution of this planet where we're living and with its adaptation to the needs of living beings. In other words, the natural cycle of the economy cannot have arrhythmias like those of the conjuncture but follows a constant progression of development in relation to the relatively stable environment state in the long term. The cycle rhythm marks a deviation from the stability path, then following a development line that moves in partial disagreement with the natural evolution.

The social order is following the model dictated by the instability of the economy, on the assumption that this rhythmic world is the norm and not a disharmony. So that it seems normal that the governments in charge look to the conjuncture to assess the consensus degree they have. A consensus that tends to contract, however, if the economy falters. Actually, the right measure should be the relative stability of the economic progress over time and not the ups and downs of the economy.

There is certainly a fundamental discontinuity between the rational tendency of the community and the position of the various leaderships that measure consensus on the basis of the current economic situation. In fact, the common feeling inside a community is directly influenced, though implicitly, by the natural tendency of economic systems to follow the straight path of stability, according with the slower evolution of the natural state. Therefore, it follows that the community, understood as a set of institutions, business companies and families, is inclined to believe as consequent a growth of the economy without arrhythmias and slowly but continuously growing. Therefore, the economic turnaround is considered unnatural and a mistake to be taken against the current leadership.

While the measurement standard of the community is the growth of the economy constant and balanced with the needs of natural world around us, the leaderships rely for their fate on the conjuncture anomaly. This means that the community follows the natural stability model as a yardstick. The leaders, on the other hand, are forced to deal with the economic situation in the short and medium term, that is with the result of errors in the economy management, accumulated over time.

It follows that for both the community and the leadership points of view the nightmare is the recession. The fact that it's a punishment for breaking the relationship with nature, however, is beyond the understanding of the leaderships used to act on the basis of short-term effects. On the other hand, the community, with its strong natural orientation to the linear growth of the economy in the medium and long term, has the main goal to restore the linear growth and to put back on the balanced path the economy in crisis.

This discontinuity of judgment however leads to fear and to remove the conjuncture inversion seen as a negative trouble. And it is certainly negative. Not only because of the subsequent discomfort effects, but I would say particularly because it is a factor of social imbalance that alters the income distribution and wealth to the detriment of the lower classes. However, are quite different the goals proposed by the community or by the leadership in charge.

In fact, the leadership, facing an unexpected cyclical reversal, will try above all to restore the positive trend of the cycle Thus, to achieve this primary objective the proposed social balance will be completely or partially abandoned. Then in the case of Italy, the community had repeatedly expressed support for political groups that were promising a greater social balance in terms of income distribution. The unexpected and sudden economic reversal of the Peninsula undoubtedly 
undermined this prospect. In fact, for the community becomes prevailing the need to restore the linear trend of economic growth, which is in the DNA of the social group, in line with the balanced growth followed by the stable economy in accordance with the environment.

In view of this, it could appear that in the next consultations the Bel Paese (Beautiful Country) would move in favor of the political group that prefers programs to restore the correct route of the economy. Therefore, people could also accept the hypothesis of a brief recession provided that the route to linear growth is assured. Otherwise, the current leadership sees the ongoing recession as a terrible trouble and will try in every way to get the exhausted economy back on track. With minimal results, however, because the Italian high public debt puts out of business the possibility of fiscal policy intervention. By the way, monetary policy has long been accommodating and, moreover, is managed by the ECB, then beyond the control of national governments.

Therefore, it seems acceptable that in certain situations the collectivity of a country would accept a recession possibility, as a remedy to reduce the instability of the economic system. It must first be agreed that the community feels as reference for its actions the relationship between the economic and social situation and its compatibility with the environment that sustains life. It follows that, at least gradually, the collective consciousness must follow the natural direction, which is aimed to maintain or to push the economy on the track of stability and linear growth.

Now, this tendency is implicit in economic systems. Therefore, with the elasticity typical of natural relationships, it should influence the community behavior, given that the objective is generally the stability of the systems. In reasonable but not short times, we can admit that the community accepts the recession because it's the remedy required by the natural system to correct the deviation suffered by the unstable system. Nevertheless, the recession is hateful, principally because is usually increasing poverty and widening the income gap against the lower classes.

For this reason, the fall into recession shouldn't be an unexpected and uncontrolled event. But it should be applied instead to unstable systems in a scheduled form, in order to reduce as far as possible, the social damage that the recession event causes on the economic structure. It's therefore essential to have a public budget able to bear the financial cost of measures to support unemployment and people without income. Not a sort of curse then, but an event to be planned, which aims to correct the altered and unstable economy due to the accumulation of errors made in the economy governance.

In other words, the management of the economy must support the evolution of systems according to the stability linear growth. The rupture of the linear path traced by stability is usually due to attempts to force the economy march in its supportive and close relationship with the natural environment: that is, the attempt to live beyond the available resources, by forcing the development gradual march with speculative finance. The rupture of the development linear path can also be induced by factors external to the economy of a country, due to the global context influence, to the science and technology evolution, to contingent natural reasons. But apart from those factors that diverted the system from its stable path, there is always the immanent obligation to give back the stability to the deviated economic systems.

Nor could be interpreted differently the tendency to recession of the systems, which ultimately should be seen as a tendency to return to stability. Not a bad thing, certainly. But a treatment for the evil that forces the system to fall into the instability sub-world, so causing the rhythmic trouble of conjuncture cycles and the developmental anemia as alternative to linear growth. In other words, the economic situation cycle is the natural correction mechanism that activates the recession with temporal cadences, accelerated by the greater instability of the economic system.

\subsection{The Fight Against Recession Can Be a False Objective}

The fight against the recession can therefore represent an escape from the problem rather than a solution to the problem. In the sense that the issue to be resolved is not the recession, which is the consequence of a disease, but the errors that derailed the economic system from the stability path. From this point of view, a fact appears certain: escaping the recession does not mean to solve the problem of progressive instability inside the economic systems.

Rather, it means taking just a "sideway" that mitigates the effects of the coming economic turnaround and thus defers to a next future the issue of the system rehabilitation to stability. Thus, the antirecession therapies used, some even successfully, are just a temporary consolation and a delay until an indeterminate but certain tomorrow, where the lost stability will be recovered. Nonetheless, this stability recovery goal cannot be declined and bypassed, and therefore will remain as an undesirable presence on the economy scenario, despite the ephemeral success of the natural recession postponement.

It should be considered also that it's probably false the thesis that sees a next global recession as the expected result after ten years of global economic relative progress. First of all, it should be noted that North America, China and India have benefited from a long period of positive cycle, of which instead other countries, like Italy, part of Europe and Latin America, have benefited only partially. But above all, it must be said that the alleged regularity of the economic cycle is a mere fantasy that appeared possible in the 1960s, when the instability was still limited. 
In such circumstances, we could witness a certain regularity of the cycle depending on the fact that the recession event is still weak, and the cycle wave is long. The situation in today global world is different. The scenario is dominated by deflation rather than inflation. The economic situation wave is flattened and oblong, due to the weak strength of the economy and the tendency to price deflation.

Applying today the consequences of a typical scenario of the great global inflation years, makes no sense. Therefore, it's not reasonable to believe that the long positive wave in the last decade must end with a recession. The current economy is under the deflation constellation. It's like saying that the recession is always in the balance and if it's appearing late on the scenario, this depends on the interventions of fiscal and monetary policy, which alternate to avoid the risk of a cycle fall. The evidences of this action to support the cycle are quite clear.

The increase in global debt that hits $325 \%$ of World GDP, rises the record of $\$ 217$ Trillion. ${ }^{1}$ The balance sheets of the large Central Banks in Europe, USA, Japan and China have expanded as a consequence of extraordinary interventions, like the Quantitative Easing (QE). The abnormal increase in public debt, due to ultra-Keynesian deficit interventions, has slowed the cycle fall during the 2008-2010 financial crisis, but has then become a necessary component to hold the recession that remains in the balance.

Our world tends towards recession and the fall is curbed and slowed by fiscal and monetary support policies. As to say that maintaining control of the financial crisis and the following severe recession in 2008 - 2010 may have imposed a very negative legacy. The tendency towards deflation and recession, controlled by policies at the limit of rational equilibrium, has become an inevitable partner for the world economy.

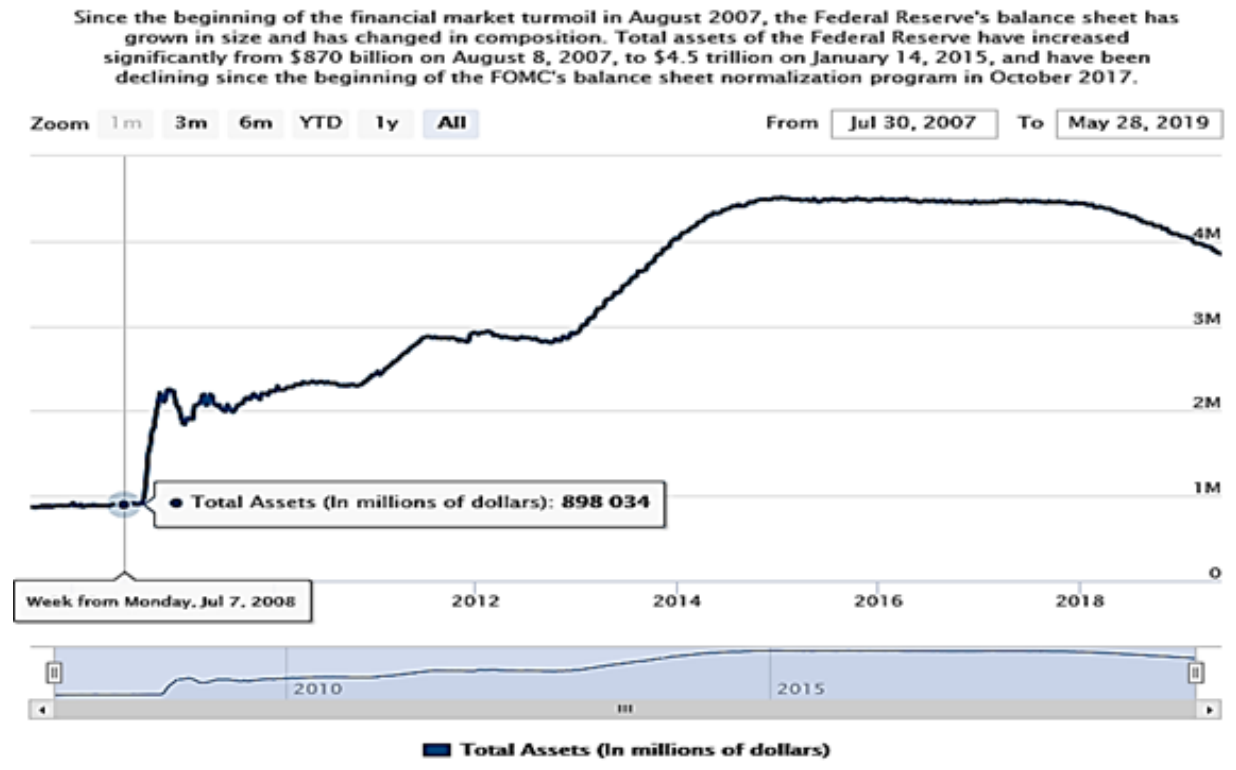

Figure 1. FED: recent balance sheet trends

\footnotetext{
${ }^{1}$ In its Global Financial Stability Report, the IMF highlighted the potential risks posed by the build-up of non-financial sector debt in the G20 (i.e. the debt held by households, governments and non-financial companies). In 2016, this debt totaled US \$ 135 trillion, up from US \$ 80 trillion in 2007.6 Indebtedness has risen differently in advanced and emerging economies. Advanced economies built up huge debts before the crisis erupted, but their overall level of debt has remained relatively constant in the subsequent decade: as a proportion of GDP, modest deleveraging by households and financial institutions has been offset by increases in government debt resulting from stimulus spending. Meanwhile, signs of strain are evident in parts of the corporate debt market. According to S\&P Global, 162 corporate defaults worldwide occurred in 2016, the most since 2009 and up from 113 in 2015.7 The debt-to-equity ratio of the median S\&P 1500 company (excluding financials) has almost doubled since 2010 and is now well above its pre-crisis level. In emerging markets, by contrast, aggregate debt levels were relatively low and stable prior to the crisis but have increased sharply since. This is especially true in China, where debt issuance has surged to help deliver the high levels of growth the country's plans require. The rapid expansion of debt in the Chinese economy is now one of the world's clearest flashpoints for potential economic turmoil: according to some analysts, China's current credit trajectory is "dangerous with increasing risks of a disruptive adjustment."
} 
- Q3 2017

- Q3 2018

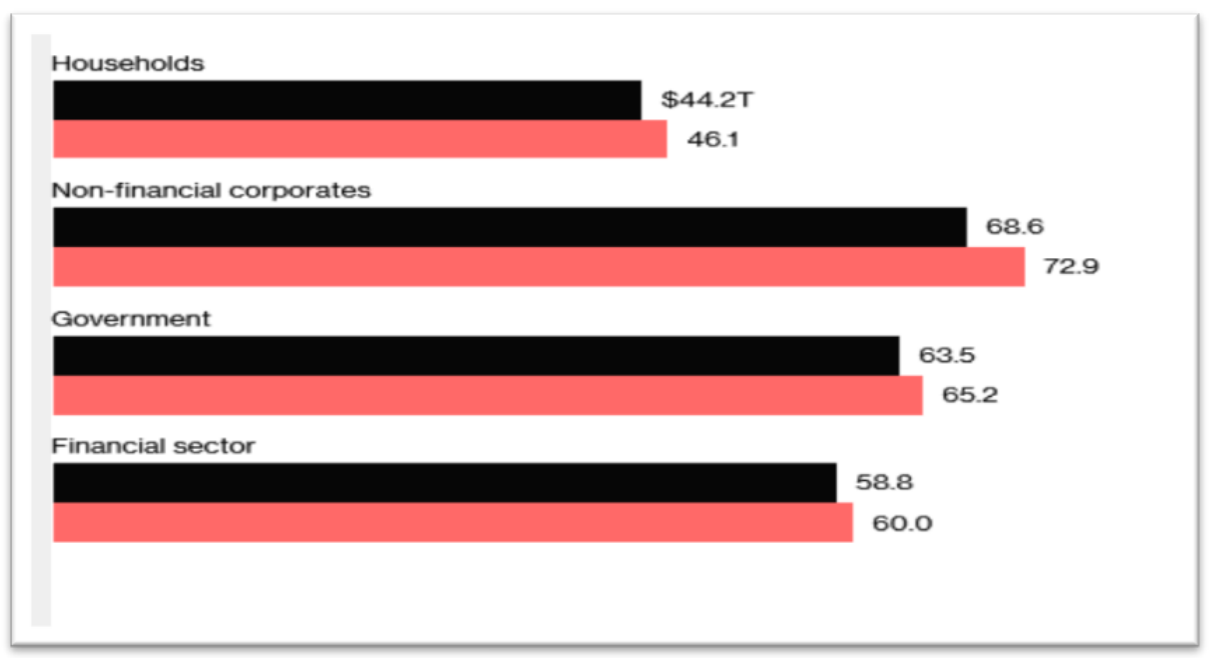

Figure 2. Sectoral Debt. Overall, global debt has grown to $\$ 244$ trillion as of third quarter 2018

\section{Source: Institute of International Finance}

The tendency to increase global debt and, at the same time, the expansion beyond the limits of public debt to support the weak cycle have therefore become the unavoidable aid for the weak development of the economy, which otherwise would be prey to a global recession. Moreover, it's difficult to control because the resources in the hands of governments and Central Banks to mitigate the bite of the crisis have already been abundantly overused.

Indeed, the recession is not a sentence, but a remedy. Postponing the treatment is not a good practice, especially since the controlled and articulated recession within countries and continents can be tolerated, somehow parrying the social imbalances created by the growing unemployment. Very different is the case of a recessive event spreading at a global level, with effects that therefore are cumulating and reflecting from one country to another, with defensive measures that may worsen the general context.

An advance of this generalized recession scenario was already experienced during the financial crisis post-speculative excess in the first decade of the 2000s. Although very serious and intense, the episode was partially absorbed and somehow postponed through the fiscal policy therapies, the accommodating policy of Central Banks and the use of extraordinary interventions, such as the QE.

The problem is therefore the recession in the balance that is stopped just on the edge, so remaining unstable because fiscal and monetary policy therapies can postpone its fall over time but cannot or do not seem to be able to definitely resolve the falling danger. It follows that it could be envisaged an irreparable disruption, at least for now, between the community dynamic evolution and the adamant belief of leadership. On one side, the community follows the guiding star of linear growth and therefore feels the recession as a signal for the search of new leaders, able to reconnect the economic system to the environment evolution. On the other side, the political teams are instead anchored to the naive belief that political maneuvers can solve the problems of the economy and therefore giving new substance to the consensus, which instead is waning.

This disarticulation between dynamic trends of the community and the singular inertia of the government rulers who continue to use the instruments of politics relentlessly, just to maintain their leadership, could remain unexpressed. Nevertheless, it could be just quiescent behind the false hopes of recovery of economic and social welfare, arising from the precarious good weather that the political resources can manage to obtain. It's therefore possible to create a sort of precarious balance between the community's chosen direction and the usual one taken by the government rulers. A precarious balance that however involves a slow erosion of consensus, though such as not to undermine the stability of governments, at least in the short term.

The community is in any case always looking for the economic condition that would put the economy back on the path of linear development. It can therefore stay "at the window" to check if the usual therapies used by the leadership in charge can really bring the economic system back on the stability path. Now, it's clear that the time for clarification can expand because, as we've seen, Keynesian therapies can be successful provided they are not misused and do not involve debt 
excess. However, if the condition of the relative health of the public budget would not be respected, the "wasted effort" of the usual intervention measures to support the conjuncture will have no effect. That is, they have a moderate and temporary outcome on the conjuncture destiny.

At this point we are in the current situation. In many economies the scenario shows a looming recession that can only partially be reflected in a future increasingly near.

\subsection{Over-Indebtedness and Recessionary Trend}

The disarticulation between the intervention lines of a government and the community feelings can continue until a scenario of recession in the balance. Governments could continue on the path of fiscal policy intervention and the Central Banks on the path of accommodative politics, although the results of these strategies may be exhausted very soon.

Instead the community is projected not so much to maintain the status quo but rather to find the way in order to bring the economic system back to its natural stability. Therefore, the system fall into recession may not be considered an error in the leadership action, because the reversal of the economic situation can bring the altered mechanism of the economy back into balance. Especially if the system fall is somehow attenuated at the social level with a program of interventions in favor of the most disadvantaged categories.

Since the awareness of the communities is shaped according to the natural model, we can admit that the perception timing of the implicit message about the return to stability is long, according to the environment evolution times. This possible community delay in the reception of the natural message should also consider the long action times of fiscal and monetary policies, thus postponing the perception of the changing cycle. It follows that if the recessionary trend in the global scenario lasted for a long time, we could have a purpose convergence of communities at global level, to accept a planned recession, rather than a further immanence of the phenomenon still in the balance.

We could put this last scenario of common purpose of the masses at global level next to the current scenario in which, at least within most developed economies, the communities feel the weight of an imminent event (the recession), although continuously postponed by the choices of the government rulers, just interested in maintaining their seats.

This reminds us that the economic system has a sort of flexibility, which can report about the relationship between the immanent nature and the mankind, often distracted from its obligations towards the natural environment. Well, despite this carelessness, the environment for its part has shown a tolerance telling a lot to us about the gradual adaptation of life to our planet. Well, it appears evident that the human development line follows a course that is largely orchestrated by the development of knowledge and technology. These tools of human thought are allied to the nature and then they are the mediators against the coherence progressive narrowing of the relationship between humanity and nature.

It follows that also the relationship between social organization (like income distribution) and economy must therefore tend to a greater harmony, in some way supported by the technology and knowledge development. But the approximation process of society and nature positions can take place not only over long periods of time according to the human standard. It can also occur with disruptive and largely unexpected phenomena, if will continue the disharmony between the repetitive position of leaderships and the feelings of community towards the nature call. We have already mentioned the alternative: to acknowledge that the return of the economic system on the natural stability path has an inalienable character and sooner or later must prevail.

Having applied all this to the current scenario in many continental countries and areas, we must acknowledge that an improper relationship is being created in the global economy between liquidity availability and supercharged credit and growth. A relationship that leads to a continuous increase in liquidity (and credits) to give space to a growth anyway weakening. So that if the link providing new liquidity and new credit is disconnected, the system gets jammed, with unexpected forms of decline.

Then obviously the leadership managing the economy wants this flow would not stop. And not only in countries like Italy suffering from severe financial fragility, but also in the case of the largest world economy that sees the White House pressing for a cut in interest rates. ${ }^{2}$ Then also across the Atlantic they are chasing the vain and dangerous hope that a more accommodating currency can give breath to an economy expected to grow in 2019 at a rate of around $2 \%$. In other words, the hybrid link between abundant liquidity and (weak) development is now stable even in the strongest economies.

The hope driving the holders of fiscal and monetary policies lies in the favorable turn the economy could have due to the new support measures. Actually, it cannot be denied that the residual energy of economic systems could give the

\footnotetext{
${ }^{2}$ In one of his morning tweets, the 45th American president wrote: "China will inject money into its system and will probably cut rates, as always, to compensate for the business it is losing and losing. If the Federal Reserve were to never do the same, it would be game over, we win! In any case, China wants an agreement ".
} 
appearance of a real recovery. It remains, however, that the unstable system with continuous support interventions, has bypassed the natural correction that sooner or later will enforce its reasons for the unstoppable pressure towards the economic and social stability.

However, the gap between community tensions and leadership programs is bound to be covered. First of all, the insistence on supporting fiscal policies and accommodating monetary policies can only be exhausted if the expected and proclaimed results are not achieved or produce just ephemeral results. At this point, even with new political programs restarted in accordance with the community's requests, it could be assumed that the positions tend to get closer. Therefore, is opened the possibility that the natural correction, although cautiously, takes hold and so the controlled recession would be able to work.

In this hypothesis, positive I would say, it can be imagined a gradual adherence of the different economies at a turning point, accordingly with the stability need hanging over the future of economic systems. In fact, in this case, the fall into the controlled recession can invest the global economies following a long temporal succession, thus limiting the damage compared to the hypothesis of a global financial crisis like the one experienced in 2008-2010.

In other words, it's necessary to avoid that the choice of postponing to an indeterminate future the correction of unstable economic systems, could give rise to a repetitive series of financial crises, like the one suffered during the first decade of '2000. A hypothesis that could emerge indeed if we continue to supercharge the exhausted systems due to instability, with new fiscal or monetary support interventions.

That said, it's clear that the "easy credit-weak growth" trap cannot go on indefinitely and that, when the situation is forced too much, at the end there will be anyway a retreat. A retreat of the monetary authorities who, in the prolonged absence of results, may decide to cease from action. That is, to start the QT (Quantitative Tightening) in the wake of the operation started in the second half of 2017 by the Powell's FED and unfortunately prematurely aborted due to concerns on the reaction of the markets and the economy in general. That reaction - strong, above all from the US Stock Exchanges actually was the alarm bell of a corrective decline that would slow the growth beyond the potential (and therefore drugged) of the US economy, and perhaps would start a cautious recession. ${ }^{3}$

Unfortunately, the reasons of monetary policy, which has the task to promote maximum employment, stable prices, and moderate long-term interest rates, have prevailed over the non-political but structural opportunity to allow the natural mechanisms to correct the sick economy.

\section{The Fed's balance sheet}

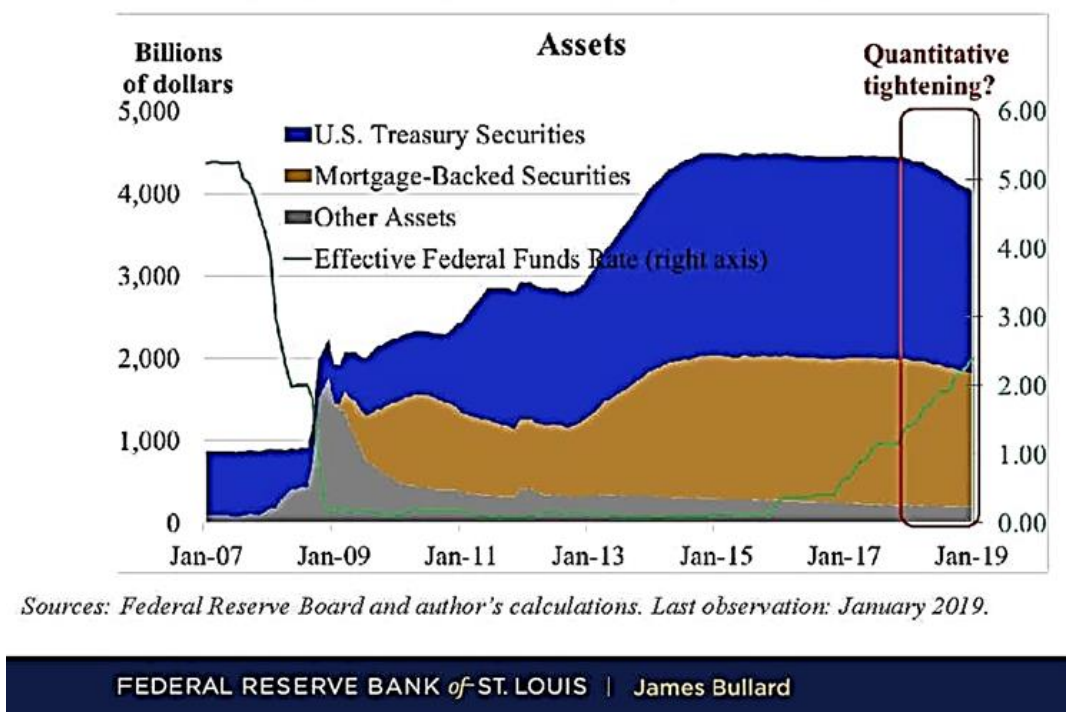

Figure 3. The Fed's balance sheet Jan. 2007 - Jan. 2019

\footnotetext{
3 Asymmetric Effects - With the policy rate near zero, the effects of QE may have been substantial due to signaling effects. Now, with the policy rate well above zero, any signaling effects from balance sheet changes have dissipated.

This means balance sheet shrinkage — "QT"_- does not have equal and opposite effects from QE. Indeed, one may view the effects of unwinding the balance sheet as relatively minor. St. Louis Fed president James Bullard discusses Quantitative Tightening (QT)
} 


\subsection{The Supercharging of the Economy Cannot Continue Longer}

The problem therefore remains open, between the pressures of the politics that does not want to change direction and the gradual opening of the community to the persistent impulses sent by the natural system for the correction of unstable economic systems. For now, it doesn't seem that there is, in the community context, a definite prevailing towards the correction and the laissez-faire of corrective recession. On the other hand, countries with illiberal, populist or definitely authoritarian governments show a total lack of reasonableness about the economy state. Often, they act in the presumption that the orchestration of the tools offered by economic policy could positively restore the exhausted economies, at least for a convenient (for them) period.

Obviously, things are not on the side of the interests of one or the other group. The future concerns the paradigm linking the economy's vicissitude to the planet evolution and its inexhaustible capacity for a self-sanitation. Ergo, we must admit that in a time indefinite about the when, but inevitable in any case, the castle built on this partisan trust would finally collapse due to the natural corrective intervention, which will be anyway unpredictable. Remaining therefore on the issue of the "easy credit-weak growth" trap characterizing the global economy, one issue seems obvious: if there wouldn't be the healing turnaround of the economy in recovery with its forces, the monetary policy that from being accommodative becomes more and more accommodating couldn't continue nonstop anymore.

Since the market seems to be very sensitive to the issue of public debt/GDP ratio, then the liberality of governments towards the deficit spending policy is now finding a fierce obstacle in the markets that penalize those countries that are expanding the use of Keynesian policies with subsequent debt increase. The case of Italy is classic, being the first of the Euro countries to experience a recession in the second half of 2018. In fact, the populist government has forced the participation rules of the single currency, which instead impose a gradual reduction of the Italian high public debt. A debt exceeding $130 \%$ of GDP and tending to rise further.

Therefore, during the formulation of the 2019 financial law, a strong tension was created with the European Commission on the issue of 2019 deficit. This conflict was immediately reflected on the money cost that jumped over $3.6 \%$ in comparison with rates just over 1.5\% in Spain and 1\% in Ireland. As can be seen from Figure 4, the Italian BTP returns have increased during the preparation of the 2019 financial law, which has seen the growing disagreement with the European Commission.

On the other hand, there has been a general dissent of the euro area countries towards the relaxed fiscal policy advocated by the Bel Paese government for electoral problems and for the feared reflexes of infection coming from the crisis suffered by Greece. It should also be said that the Italian public opinion didn't follow the government in its brusque action at European level, with the community mostly against the suggested hypothesis of an unlikely exit from the Euro. ${ }^{4}$

The market retaliation for the indiscriminate use of public spending to force the economic situation has taken shape also in the USA. The aggressive policy of the White House has led to the choice of supporting the economic situation through a tax measure that, approved in 2017, entered into force in 2018. With the aim to cut taxes for the benefit especially of the privileged categories, with a burdened public debt.

According to the Congressional Budget Office report ${ }^{5}$, the acceleration in the two-year period 2018-2019 beyond the

\footnotetext{
${ }^{4}$ For Eurobarometer "74\% of euro area citizens claim that having the euro is a good thing for the EU as a whole". This is the highest level since 2010. According to the European statistics index, almost two thirds of citizens (64\%) believe that having the euro is a good thing for their country. In Italy the percentage of citizens that positively judges the euro is still among the lowest in the euro area, but it is in strong increase compared to last year, $(+12 \%)$ and stands at $57 \%$ in favor, $30 \%$ against, $11 \%$ of undecided. In Germany the percentage of citizens who positively rate the euro is $70 \%$, in France 59\%. The highest appreciation comes from the citizens of Ireland, where $85 \%$ of citizens positively value the euro.

5 The largest effects on GDP over the decade stem from the tax act. In CBO's projections, it boosts the level of real GDP by an average of 0.7 percent and nonfarm payroll employment by an average of 0.9 million jobs over the 2018-2028 period... In CBO's projections, real GDP expands by 3.3 percent this year and by 2.4 percent in 2019 (see Summary, Table 1). It grew by 2.6 percent last year. CBO - The Budget and Economic Outlook: 2018 to 2028- April 2018

Output. Real GDP is projected to grow by 2.3 percent in 2019 and by an average of 1.7 percent per year from 2020 through 2023. Most of the growth of output in CBO's forecast over the next few years is driven by consumer spending and, to a lesser extent, business and residential investment and exports. Compared with the robust pace of output growth in 2018 - 3.1 percent, the fastest annual growth since 2005 — output growth is projected to slow in 2019. That projected slowdown largely results from an anticipated slowdown in the growth of business fixed investment, as the positive
} 
potential could be reduced to just over $1 \%$ in the following five years. Moreover, after two strong quarters, the US economy slowed down in the fourth quarter of 2018, while the stock exchanges suffered a sharp fall beyond $25 \%$. In particular, the Dow Jones went from its share of more than 26800 in August to 21800 in December 2018, while the Nasdaq decreased in the same period from 7600 to 5900.

The markets in the USA and elsewhere have trembled. However, they emerged from the bear's embrace as the Fed's monetary policy reversed its march. The Fed had planned to raise interest rates to 3.5 in 2019 and to continue the Quantitative Tightening, but the threat from the market suggested halting the planned rate march and postponing the easing of its budget. This is to say that the decline in the economic cycle, announced by the financial market, has been buffered with a sharp return to accommodative monetary policy.

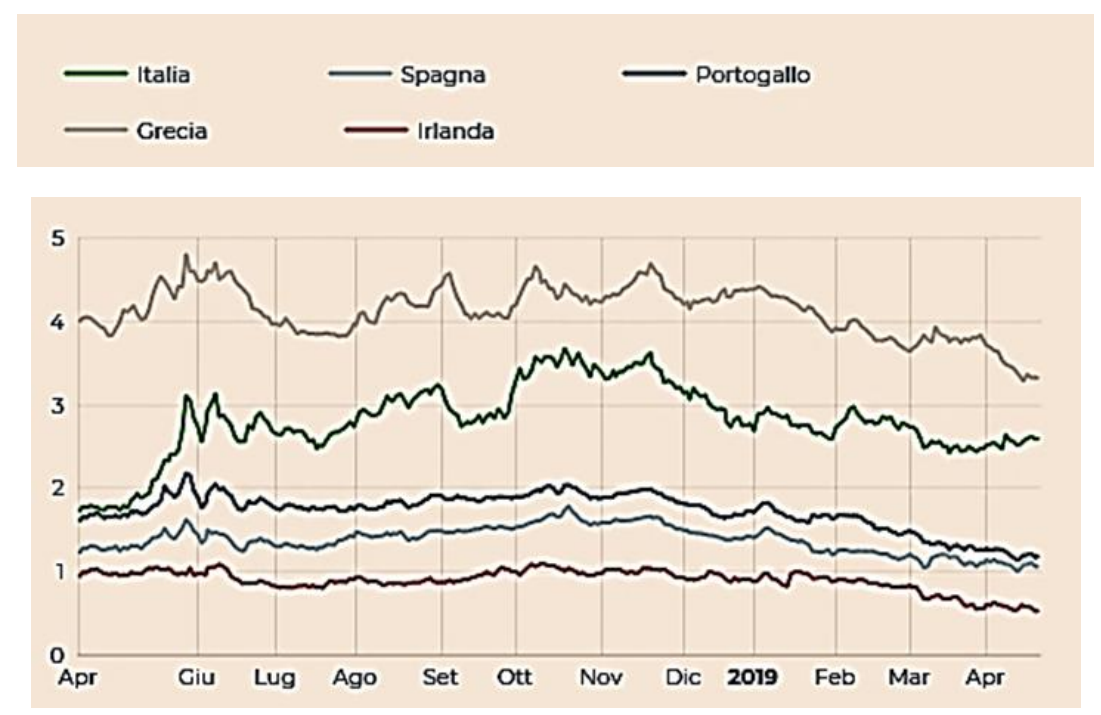

Figure 4. BPT rates in Italy against the ten-year bonds of Spain, Portugal, Greece, Ireland

Source - Finanza e Mercati di 24ore (20 aprile 2019)

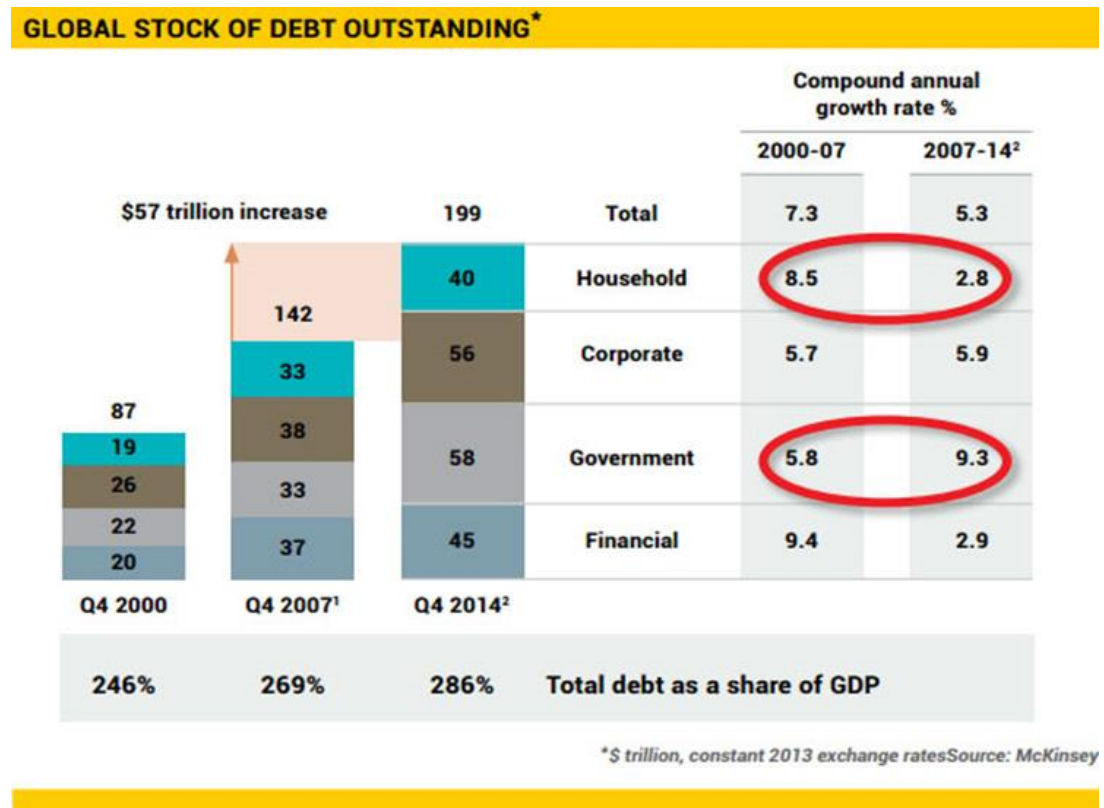

Figure 5. Global stock of debt outstanding

Source: Global-stock-of-debt-outstanding - 12th May 2016

effects of recent tax legislation on investment growth begin to wane, and from a sharp reduction in federal purchases starting in the fourth quarter of 2019 that would occur under current law. CBO - The Budget and Economic Outlook: 2019 to 2023- January 2019 
Now, the market morality is firm in condemning the excess of fiscal policy, but it isn't so willing to condemn the excess of money and cheap credit. So, if the Central Banks decide to start a more restrictive policy to reabsorb the huge asset so far acquired, the market's response could be negative. Otherwise, is applauded by the Stock Exchanges the decision to continue on the path of giving liquidity to the market. And not only that. The financial market acts as a sounding board for the economy recovery, which therefore emerges from its numbness.

Basically, the trap of "ample liquidity and (weak) growth" always calls for a new willingness of Central Banks to satisfy the market demand for liquidity and credit. The liquidity trap is therefore the cause of a discontinuity in the reaction of the markets, which are favorable to the opportunities offered by cheap credit but strongly contrary to the permissive use of deficit fiscal policy. Basically, we are dealing with a contradiction, because the fiscal permissiveness creates public debt excess, but the permissiveness of monetary policy creates accumulation of private debt excess.

It may be thought that the doubleness of market behavior, which distinguishes between public and private debt, is basically dictated by the same reason. Essentially, to support the economy growth, which in these conditions is modest but sufficient to justify the easy currency. That weak growth could be compromised by public debt excess which, against expectations, conspires to weaken the potential.

\section{Results}

\subsection{The Possibility of a Break Point in the 'Liquidity-Weak Growth'Trap}

Now it's evident that the "easy money - weak growth" trap doesn't admit any other solution, but the exit from the trap itself. In the favorable but unlikely case, the economy is able to initiate a recovery strong enough to gradually reabsorb any debt excess. It's the hypothesis on which monetary policy relies, giving ample liquidity together with the money cost tending to zero.

Obviously, this is a fragile hypothesis, though certainly not to be excluded. On the other hand, there is also an imbalance between the conjuncture cycle and the continental economies' potential: this asymmetry leaves open the possibility of this way out, even if not valid for all the economies. However, it must be said that the serious financial crisis that followed the speculative cycle of the first decade of 2000 was a global event which started from the United States and then exploded globally. This synchrony of speculation-crisis process, which then acted as a detonator to the global dimension of the phenomenon, of course is absent from current scenario. It could therefore be assumed that the repetition of the same perverse model experienced in the last decade wouldn't be possible.

On the other hand, it's clear that the monetary policy wouldn't be able to continue supplying the liquidity rivers needed to fuel the supercharged growth process. It follows that in the absence of tangible results and indeed in the presence of further narrowing results, the monetary policies must sooner or later give it a rest. It's useless to start a gradual increase in rates. Probably it would be enough to limit the supply of new liquidity to the economy, to start a slow reversal of the cycle. At this point, the recession in the balance materializes in a corrective recession, whose depth and length would depend on the instability degree of economic systems.

The scenario of the unsynchronized conjuncture can avoid a strengthening of the cascade phenomenon, such as the recession global extension. On the contrary, the different propensity of economic systems for the state of recession in the balance could start a reversal of the gradual cycle, with a fragmented distribution. But not only that: a part of the economies at a global level, less exposed to the instability viruses, could therefore be able to continue along a line of weak development, with an undoubted general advantage.

However, it cannot be excluded the optimistic possibility that the world in the balance towards the recession could overcome, safely but bravely, the impasse of prolonged instability to find therefore the way for a growth of the linear economy. We could even brood that major nations, in America, Europe and Asia, would continue in a constant development line, though contained, to absorb the anomalies of debt excess and the finance dystrophy, for the benefit of the real economy.

Obviously, this brilliant result could not be obtained under the usual cover of fiscal and monetary policy, otherwise the "easy-credit and weak-growth" trap would end up to strangle the economy. A result that may be achievable, anyway. It should be started a progressive detachment of the economy from the drug of cheap credit excess. A sudden detachment, in fact, could cause the fall into an unexpected and even prolonged recession. Therefore, if a gradual approach works, it seems possible that after a brief period of convalescence, the global economy could resume its path on a more balanced basis.

At this point, the problem can become the following: the monetary economy therapy to help the weak cycle can be the final remedy for the recovery of the relative stability of the economy. Or instead, as already discussed, such a simple way out from the supercharged world does not seem possible. Now, it's clear that neither of the two solutions to the problem can be excluded. For the simple reason that there is no sign of a precedent where an economy is long sustained with the abnormal 
support of fiscal policy, after the financial crisis of the first decade of the century and the subsequent monetary policy crisis.

Actually, it could be said that the long global crisis of 2008-2010 shows a long wake probably deriving exactly from the use beyond measure of fiscal policy to try to eradicate the devastating effects of the crisis. Now it's clear that the great speculative crises that succeeded since the eighteenth century onwards are all generated by an economy running beyond the potential. An improper development that gives a decoy to human greed and selfishness and to the false belief of a possible unlimited development.

This is impossible because the development rhythms of human societies are marked by the civilization itself, which can be defined as the interpreter of the relationship between humanity and the natural evolution around us. ${ }^{6}$ In this sense, we can believe that humanity cannot derail from the compatible development path, because the resources offered by the planet must be available also for the future generations, on the assumption that the nature needs life on the planet.

According to this point of view, the tension leading to the economic cycle supercharging is a damage that could derive from the massive use of fiscal policy to mitigate the weight of the 2008-2010 financial crisis. The advantages of tax therapy have been evident. The most serious damage resulting from a long exposure of the global economy to the winds of the cycle reversal, has been partially avoided. And above all the tears on the social tissue deriving from a very strong fall of the occupation, have been attenuated. The problem that remains is to know what is the outcome of the hard action that has placed over public finance the cost and weight of the rescue of failed or almost deceased banks and large industries, overwhelmed by the severe recession wave.

It's interesting to note that the economic support action was somewhat contained in Italy, due to the considerable public debt that exceeded $120 \%$ in 2008 . Even for the great banks weakened by the crisis, the rescue was mainly the result of a powerful injection of private capital, while only for Monte Paschi di Siena a public capital was required. The results are quite evident: Italy has suffered a loss of its income of around $10 \%$, that is more than half of the income loss of Central Europe countries and United States. This says a lot about the evidence of how it's useful having a reserve available of public money to be able to deal with the emergency.

Despite the mentioned merits, the doubt remains that the current climate of recession in the balance, supported by accommodative monetary policy, may be the result of that season of compulsive use of public money. This does not mean that faced with such an eventuality the use of the public spending strategy would be wrong. Faced with the prospect of a simultaneous change in the living conditions of millions of people under the weight of a general crisis, it's clear that any attempt to recover the economy becomes necessary, even if not necessarily appropriate.

So let's think about this long period of weak growth and progressive decline over the last ten years, furthermore with the stick of accommodative monetary policy. A weakness that tends to increase if the easy money flow is loosened, as in Europe and recently also in the USA.

Never like in current world, the inflation pressed towards the base is a sign of economy weakness and declining trend. Low inflation is a clear sign that the economy fails - without support - to grow, albeit slowly. Creeping inflation implies that the economy is supercharged by a stifling indebtedness and that there are doubts about the possibility that the credits can be repaid.

\subsection{It Makes no Sense to Believe That Central Banks Are Managed by Robots in Line With Market Needs}

Now it's either one of two things: the economy manages, despite everything, not to drown in so much debt, or the uncertain and serious perspective that we could expect is a renewed speculative push leading the system to a corrective crisis, of dimensions not so different from the one we suffered in the first decade of the century. Tertium non datur.

By the way, on one hand we witness a patient activism of the Central Banks, which seem to see a return of the economy to sustainable trends in a relatively short time. Now, the Central Banks in their actions follow their goals, which in general consist in controlling inflation and employment. ${ }^{7}$ Thus, achieving these objectives can overcome any other point of view.

${ }^{6}$ In that sort of relay race which is the history, the civilization torch is entrusted by refined but decadent peoples to those young and rough, but who have the strength to bring that civilization towards new heights. Indro MontanelliStoria dei Greci (History of the Greeks).

7 The primary objective of the ECB's monetary policy is to maintain price stability. This is the best contribution monetary policy can make to economic growth and job creation. Monetary policy operates by steering short-term interest rates, thereby influencing economic developments, in order to maintain price stability for the euro area over the medium term. The ECB has adopted a specific strategy to ensure the successful conduct of monetary policy. The ECB has defined price stability as a year-on-year increase in the Harmonised Index of Consumer Prices (HICP) for the euro area of below $2 \%$. In the pursuit of price stability, the ECB aims at maintaining inflation rates below, but close to, $2 \%$ over the medium term. ECB's monetary policy 
However, we cannot believe that the Central Banks are directed by robots in line with the needs of the market and the Stock Exchanges. Ergo, we must have faith that, sooner or later, the concerns raised by the long stay on the market of next-to-zero rates would occupy a prominent place in the monetary policy decisions.

This would suggest that sooner or later the game would end, and the gradual absorption of liquidity excess would start. At this point, the problem is that the insolvency of many debtors will lead the economy, already close to recession, to the feared economic turnaround. This possible eventuality should see the board of the Central Banks able to resist the insistent requests for intervention, still accommodating. Otherwise, the crux of the "easy liquidity-credit" trap will once again stifle the economy. Which will react suddenly with a new unexpected speculative action, until the corrective crisis.

The current difficulty may have originated from the reaction of states to the traumatic event of the financial crisis of ten years ago. The deployment of ultra-Keynesian defense policies may have a dark side. It didn't allow the global economy to swallow the mass of debts created by the speculative euphoria and essentially unsustainable. Instead, it allowed the renewal of bad debts through new credit, while public finance absorbed part of this burden, with the rescue of banks by public capital. It seems evident therefore that the tenacious and decisive corrective action, which follows the crazy headlong rush of speculation, has been repressed at least partially by the strong action of fiscal policy.

It can be deduced that the economic system has been amended of excesses only partially and that therefore the instability state remains. It could be said that the partial closure imposed by the crisis on the process of the economy financialization has created (so to speak) the conditions to reproduce the liquidity injection, responsible for the crisis itself. In other words, the reaction seems to be paradoxical, with the attempt to recreate the conditions that had allowed the sick growth of the economy during the speculative phase.

Now, the exit from the financial crisis thanks to fiscal policy has left the deflation tendency and a weak growth. Conditions that are interpreted as a weakness of the economy just coming out of the crisis. And, instead, they are the unintended fruit of the rough action of the fiscal support policy, which has left unsolved the natural project of the economic system return to the stability. The economy's weakness, when is coming from the financial crisis (abbreviated), is therefore due to the unsolved instability.

It follows that the therapies adopted were made just to give support to the tired economy and certainly not to allow, maybe gradually, to progressively clean off the remains of the great speculative crisis. In some ways, we acted by letting ourselves be carried away by the desire of the markets to resume the march interrupted by the crisis. Although the reasons were more noble.

The monetary policy always accommodating in response to low inflation and the stainless tendency to use the public spending, even in the case of excessive public debt (as in the case of Italy), have opened the way to liquidity flow and easy credit. Acting in this way, politics moved in harmony with the institutional operators and the market. From previous Figure 5, it can be observed the development rapidity of debt from 2008-2010 to today at a global level.

Now it doesn't seem that the core issue has been correctly interpreted. The legacy of the crisis was the residual instability of the global economy, also due to the unusual use of fiscal policy. Then not a normal exit from the adverse cycle that may require support. Well, the answer given by companies, community and institutions has been a sigh of relief and the request for support to give breath to the cycle. But this interpretation seems to be a simplification.

Indeed, we are faced with a different global interpretation. We must take into account, in interpreting the current condition, that the speculative-financial crisis that hit the economy in the first decade of 2000 had portions equal to that which hit the world in '29.

We must therefore reflect on the rapid exit from the crisis in the recent speculative event compared to the over ten-year delay that blocked the worldwide economy of the 1920s.

In fact, to believe that the strategy of massive use of public spending and accommodating monetary policy would be the sufficient key to resolve, from now on, the repetition of speculative events, could be an excessive naivety. As demonstrated, nonetheless, by the reaction of the post-financial crisis economy, we have witnessed in fact a long weak economic wake and the continuous presence of deflation as a companion. We must agree that this unexpected outcome of the post-speculative financial crisis is the key to follow in order to ascertain the reasons for the current deadlock, which we have defined as "economy in the balance".

Stable prices and confidence in the currency are the two main criteria for monetary stability. Stable prices are maintained by seeking to ensure that price increases meet the Government's inflation target. The Bank aims to meet this target by adjusting the base interest rate, which is decided by the Monetary Policy Committee, and through its communications strategy, such as publishing yield curves. BANK OF ENGLAND. Monetary policy 
After the prolonged liquidity injections and the rantings of fiscal policy (like the latest realized by the United States with the tax cut), we are still witnessing a condition of the global economy in the balance, that is waiting for a recession, which is withheld by the usual outdated measures.

\section{Discussion}

We can recall at this regard that during the development of the great crisis, there was a new sharp depression in the economy after the mid-30s, from which the world came out only with the First World War.

The US economy shrank 50 percent in the first five years of the depression. By 1933, the country had suffered at least four years of economic contraction. It only produced $\$ 57$ billion, half what it produced in 1929. That was partly because of deflation. The Consumer Price Index fell 27 percent between November 1929 to March 1933, according to the Bureau of Labor Statistics. Falling prices sent many firms into bankruptcy. The BLS also reported that the unemployment rate peaked at 24.9 percent in 1933. New Deal spending boosted GDP growth by 10.8 percent in 1934 . It grew another 8.9 percent in 1935, a whopping 12.9 percent in 1936, and 5.1 percent in 1937. Unfortunately, the government cut back on New Deal spending in 1938, and the depression returned. The economy shrank 3.3 percent.

In the case of Germany, the Weimar government failed to respond effectively to the crisis. Heinrich Bruning, who became chancellor in March 1930, feared inflation and budget deficits more than unemployment. Rather than spending to stimulate the economy and create jobs, Bruning opted to increase taxes (to reduce the budget deficit) then implemented wage cuts and spending reductions (to keep prices low). Bruning's measures failed, and probably increased German unemployment and public suffering rather than easing it.

In the case of Italy, apart from the reasons that may have generated its new involvement in the 1930s, it seems appropriate to point out that the correction of stability, now as then, is a long process that requires great patience of institutions and communities. The hope that we can, with the magic of the economy's tools, solve this lassitude of exhausted systems due to a supercharging, may seem a simplification and the attempt to just go with head in the sand.

The Great Depression of the 1930s could be interpreted as the sign of a system seeking to recover stability, but nevertheless the first cycle wave of the '29, though very sharp, was insufficient to resolve or at least strongly mitigate the problem. ${ }^{8}$ If we would make this interpretation our own and could therefore transfer the experience of a hundred years ago to today, we should see various similarities with a possible potential new fall in the global cycle. These are obviously just mere hypotheses, because the economic adventure is rarely repeated over time with the same sequence.

One thing however seems to be confirmed. The great crisis of the first decade of the 2000s does not seem to be overcome, as didn't that of '29 of the last century after the first sharp recessive wave. On the other hand, we can admit that the similarities between the two events can be finally put aside, also because in the last 10 years we have massively used the potential strength of fiscal and monetary policy, unlike what happened in the 1930s. At the time, on the contrary, monetary policy under the blows of the crisis soon became restrictive and finally it was decided to return to the post-war Gold Standard. which essentially increased the malaise feelings (Bernanke, 2000)

A potential relapse into the crisis may not be excluded, even if the order of this possible new correction wave of the system seems unclear due to the powerful action of politics on the economy's body. As saying that the concurrent action of the fiscal policy firstly and the accommodating monetary policy later, could be a sort of blandishment, enough to contain the intensity of the phenomena, but not to appease them. If this were true, the strength of the pending recession could be less severe than expected, especially if appropriate precautions would be taken.

In this context of hypotheses, we can try to evaluate the influence of neo-Keynesian interventions, like those implemented in Italy and in the USA, as well as the consequences of recurrent incidence of monetary policy. Since the potential solution of the current scenario is to slow down the liquidity and easy credit flow, it could appear that these initiatives, let's say somehow populist, are incompatible with the mysteries of the economic law. Therefore, there is the risk to complicate the economic situation of the global economy, then not only of the individual countries subject to these initiatives.

\footnotetext{
${ }^{8}$ Regarding the double cycle fall during the 1930s, we should recall that the cycle fall was intensified by the decision to keep the Gold Standard during the severe crisis. That decision worsened the adverse cycle effects, actually sharply reducing the liquidity and increasing the credit crash. Now, the stifled economy for lack of liquidity is by the way just an extra effect, added to the correction in progress. As such, the context worsening doesn't seem neutral regarding the natural correction program, which is showing to have its logic and shape and doesn't seem to be modified or even just relieved of the contemporary deterioration due to monetary factors. In this sense, it can be argued that the double economic inversion of the 1930 s can be motivated by the incomplete correction of the unstable economy, while didn't interfere the monetary error that at the time anyway strongly limited the liquidity.
} 
A recent appeal by the IMF sees in the trade struggle between the USA and China, recently at loggerheads, a danger for the global economy. Not only and not so much for the possible damage caused to the trade and growth of the world economy by the return to the past regarding duties. But also, and maybe more because of the unconscious and underlying dangers that the growth degradation of the main emerging economies can trigger. The light troubles of the financial markets at the end of 2018 and spring 2019 may be just the initial signs of a new recessive wave. A corrective wave that could find fuel to spread over the sea of debt excess that doesn't have an appropriate counterpart in the real economy.

In this adverse hypothesis, it can be considered that the natural correction imposed by the continuing instability of the economy would in turn be neutral regarding the cycle worsening deriving from the liquidity and credit excess. Thus, we risk an intensity of the conjunctural reaction that could be similar to that experienced in the 2000s. As at that time, in fact, the instability crisis has now been reinforced by the excesses connected to the speculative crisis: these excesses seem to be unloaded separately from the process of instability natural correction.

Beyond this foggy quantity of various hypotheses, the fact remains that the need for stability of economic systems requires from time to time some pauses that we can call "recession". To escape or to try avoiding this imperative is a probable error that hides these difficulties to the communities involved.

A good governance of the economy - one might think - lies principally in the capability of rulers, institutions and communities to be sensitive to the call of nature and therefore to follow the guidelines for a sustainable economy. In other words, institutions and communities must aim to favor an adaptation of the economy management to a sobriety of intent and objectives, according to the natural course of our planet when we use its resources. Unfortunately, the failure of this difficult balance is paid with the instability and the accumulation of economy and price cycles. To believe that the errors made on the path of sustainability route can be solved by ultra-Keynesian good intentions or by new liquidity seems more and more a true naivety.

\section{Conclusion}

In short, we need to clearly distinguish the reasons why the world today is in the balance. What we are experiencing is a stressed economy, because we do not leave the automatic correction mechanism free to do its work and, moreover, we intend to intervene continuously with support maneuvers. Following this line of reasoning, the treatment for the gradual return to economic stability is to allow, with all the appropriate precautions of course, the recession. This is because for the moment there isn't any real possibility that maintaining the current mechanisms could allow to give again stability to the systems.

The secret hope that the US economy, through the powerful injections of ultra-Keynesian interventions, could finally break the instability chains is probably just a hope. Actually, the sinuosity of the US economic development line in 2018-2019 cannot be considered a singularity within a world otherwise on pause. Therefore, we can see only two perspectives.

The first perspective proposes that during the next few years the North American economy should return to a development at a very slow pace, like the Europe of the euro area and many Asian countries: this hypothesis, somewhat benign, allows to foresee a cautious economy evolution in the coming years, if not slightly declining. In perspective, the natural force driving the systems towards stability, a patient but irrepressible force, would trigger gradual and fragmented recessions, somehow manageable especially in those countries that kept a virtuous behavior in the use of public debt.

This hypothesis obviously requires that institutions, governments and communities are willing to face the sacrifices necessary for the return to stability. Communities are the natural receptors of the implicit and explicit messages continuously produced by the natural system. Since the communities create institutions and governments, it's not so unlikely that this benign hypothesis could be realized.

The second perspective, not benign unfortunately, postulates that the current mechanisms would insist also in the future. With the result that from the USA in America and from China in Asia or anyway from one of the leaders of the global economy, could arise a new speculative storm that, like the previous one, would have a worldwide repercussion. In this second case it would be the greed and the selfishness of men to force the terms of nature and to impose always the human sovereignty.

America and the world need a new Reagan and a leadership like the one who believed in the recession as a tool to re-launch a new period of human development.

\section{References}

Bernanke, B. S. (2000). Essays on the Great Depression. Princeton University Press - Princeton, New Jersey.

Cardoso, E. (1992). Inflation and Poverty. in NBER Working Paper \# 4006. https://doi.org/10.3386/w4006

Cargill, T. F. (1997). The political economy in Japanese monetary policy - HUTCHISON, TAKATOSHY Massachusetts 
Institute of Technology, 1997. https://doi.org/10.7551/mitpress/5440.001.0001

Congressional Budget Office USA - The Budget Outlook for 2018 to 2028.

Cossiga, G. A. (2017). Stability and Instability of an Economic System: Considerations. Review of European Studies, 9(3), 2017. https://doi.org/10.5539/res.v9n3p8

Cossiga, G. A. (2018). A New financial crisis could start again from the US. Advances in Social Sciences Research Journal, 5(11). https://doi.org/10.14738/assrj.511.5521

Cossiga, G. A. (2018). Signals from the World of Economics. The Price Constant and the Democratic Issue. International Journal of Social and Administrative Sciences, 3(1), 1-21.

Cossiga, G. A. (2018). The Search for Inflation on a Constant Basis at 2\%. International Journal of Science, Social Sciences.

Dornbusch, F. (1993). Moderate Inflation. World Bank Economic Review, 7, 1-44. https://doi.org/10.1093/wber/7.1.1

European Central Bank - Press Conference. Mario Draghi, President of the ECB; Luis de Guindos, Vice- President of the EC. Riga, 14 June 2018.

Friedman, M. (2007). On economics - Selected Papers - University of Chicago Press.

Geithner, T. F. (2014). STRESS TEST - Reflections on Financial Crises - RH Business Books.

IMF - International Financial Statistics - Database, various years.

IMF - World Economic Outlook Update, July 2018.

Inquiry Report (2011). THE FINANCIAL CRISIS" - Final report of the NATIONAL COMMISSION on the causes of the financial and economic crisis in the United States - Official Edition.

Kindleberger, C. (1973). The World in Depression: 1929-1939. University of California Press.

Krugman, P. R. (2008). The return of depression economics and the crisis 2008" W.W. Norton \& Company, New York.

Krugman, P. R. (2012). End This Depression Now - W.W. Norton \& Company, Inc. New York.

Lindberg, L. N., Maier, S., \& Barry, B. (1985). The Politics of Inflation and Economic Stagnation: Theoretical approaches and international case studies. Brookings Institution - Washington D.C.

Mirrlees, J. A. (2006) Welfare, Incentives, and Taxation. Oxford University Press (1 June). https://doi.org/10.1093/acprof:oso/9780198295211.001.0001

Raines, J. P., \& Leathers, C. G. (2008) Debt, Innovation and Deflation: The Theories of Fisher, Schumpeter and Minsky. Edward. Elgar Massachusetts.

Reinhart, C., \& Rogoff, K. S. (2009). The Time Is Different - Eight Centuries of Financial Folly. Princeton University Press - Princeton and Oxford. https://doi.org/10.2307/j.ctvcm4gqx

Roach, S. S. (2009). The next Asia - Opportunities and challenges for a new globalization. John Wiley \& Sons.

Roubini, N., \& Stephen, M. (2011) Crisis Economics: A crash Course in the Future of Finance. Penguin Books.

Sargent T. J. (1982). The Ends of Four Big Inflation" in "Inflation: Causes and Effect" University of Chicago Press Robert Hall Editor.

Schumpeter, J. (1939) Business Cycles: A theoretical, historical and statistical analysis of the Capitalist Process. New York Toronto London: McGraw-Hill Book Company.

Shilling, A. G. (2001) Deflation. How survive and thrive in coming wave of deflation.

Stiglitz, J. E. (2016). The EURO. How the common money threatens the future of Europe. W. W. Norton \& Company New York - London, 2016.

Temin, P. (1989) Lessons from the Great Depression. The MIT Press - Cambridge - Massachusetts.

Wapshott, N. (2011). KEYNES - HAYEK. The Clash that Defined Modern Economics. W. W. Norton \& Company. New York - London.

\section{Copyrights}

Copyright for this article is retained by the author(s), with first publication rights granted to the journal.

This is an open-access article distributed under the terms and conditions of the Creative Commons Attribution license (http://creativecommons.org/licenses/by/4.0/). 